\title{
DIFFERENCE EFFECT OF THE COMBINATION OF LAVENDER AROMATHERAPY AND EFFLUERAGE WITH BREATHING RELAXATION ON PAIN INTENSITY DURING LABOR AMONG PRIMIPARAS
}

\author{
Murtiningsih, Shintya Tri Andani \\ STIKes Jenderal Achmad Yani Cimahi, Cimahi, Indonesia \\ Correspondence: murty_68@yahoo.com
}

\begin{abstract}
Although labor pain is a physiological process but it was feel severe and longer for primiparas. Because of a cervical effacement earlier than dilation, and no experience of labor can affect women feel anxiety and fear of labor process, it cause increasing of pain. The non-pharmacological method was cheaper, simple, effective, and no side effect can help women to control of labor pain by herself or another person. The combination of lavender aromatherapy and effleurage can increase of relaxation of uterus contraction and between of it, so labor pain decreasing. The aim of this study was to determine difference effect of the combination of lavender aromatherapy and effleurage with breathing relaxation on pain intensity during labor among primiparas. This study used pre-experiment design with Pretest - Post-test Control Group design. The consecutive sample of 32 laboring women divided to two groups of the intervention and control group. The pain scale measured by NRS questionnaire. The results showed that mean of pain scale before being given intervention is 7.25. It was the same of two groups. The average of pain scale decreasing to 5.25 in the intervention group and to 6.25 in the control group. The result of t-test dependent obtained $\mathrm{p}$-value $=0.000$, so meaning that two of interventions was able to decrease of the labor pain. The result of t-test independent obtained p-value 0.004 , so meaning that there was significantly difference of pain scale during labor of the intervention group to compare with control group. Suggested to health care who provide services at labor room to give a combination of lavender aromatherapy and effleurage as a non-pharmacology therapy alternative besides breathing relaxation to decrease of pain labor in primiparas.
\end{abstract}

Keywords: Aromatherapy, Labor, Massage, Pain, Relaxation

\section{INTRODUCTION}

Although labor pain is a physiological process but in the primiparas it is felt more severe and prolonged. Why is that ?. Cervical effacement occurs first than cervical dilation, so the labor becomes longer and may result fatigue of women that affects increased perception of pain (Maryunani, 2010). In addition, the lack of experience of childbirth can make laboring women feel anxious and afraid in the process of labor. This situation will increase the feeling of labor pain. The other factors that may affect labor pain are age, anxiety, culture, meaning of pain, support systems, preparation of labor and fatigue (Maryunani, 2010). 
The result of study on 30 labor women found that severe pain $(73,3 \%)$ and moderate pain $(26,7 \%)$ (Tarkisah, 2009). The result study by Wulandari (2015) on 23 primiparas experienced severe pain (78.3\%) and moderate pain $(21.7 \%)$. The study was conducted by Afifah (2011) showed that primiparas experienced severe pain $(66.7 \%)$, moderate pain $(26.7 \%)$ and very severe pain $(6.7 \%)$. While in multiparas mostly experienced mild pain (60\%) and moderate pain (40\%).

Severe and prolonged labor pain causes hyperventilation so that maternal and fetal $\mathrm{PaCO} 2$ levels decrease, resulting in a slow deceleration of the fetal heart rate (Mander, 2004). Stress due to labor pain causes the release of catecholamine and increasing of adrenaline hormone. Increased adrenaline hormone causes decreasing activity of uterine and resulting in prolonged labor. While, The increasing of the catecholamine hormone causes blood flow and oxygen to the uterine muscle decreases, vasoconstriction occurs in blood vessels, maternal blood flow with containing oxygen to the fetus decreases, the fetus may experience hypoxia and potentially fetal distress (Mander, 2004). Endocrine and metabolic changes induced by labor pain may be harmful to maternal and fetal health (Mander, 2004).

Various methods used to reduce the pain of labor both pharmacological and nonpharmacological measures. The pharmacological method is more effective than nonpharmacological method, but that is more expensive and it has the potential to have side effects on both the mother and the fetus. Non-pharmacological methods are nonintrusive, noninvasive, low-cost, simple, effective, and without adverse effects and allow the mother to control her labor pain (Brown, 2001; Maryunani, 2010). Various non-pharmacological methods that can be done to reduce labor pain are acupressure, acupuncture, breathing relaxation, aromatherapy, hydrotherapy, effleurage, TENS, hot 
or cold stimulation, hypnosis, biofeedback, touch and massage. Many of these nonpharmacological measures require special training. The list of 10 common nonpharmacologic childbirth pain-management, the only listed technique that was not taught in the majority of classes was aromatherapy.

The aromatherapy methods can improve physical health and it affects emotion of person. The access of aromatherapy through nasal inhalation is much faster than other ways (Koensoesmardiyah, 2009). The lavender is one of the essential oils safe to use by laboring women to improve relaxation and to reduce pain during labor. The lavender oils provides a calming effect (Hobbs, V, 2013, \& Lowdermilk, 2013). The results of study by Tarkisah (2009) found that inhalation of the lavender aromatherapy decreased labor pain of primiparas.

The non-pharmacological method of effleurage is light, stroking, superficial touch of the abdomen, in rhythm with breathing during contractions (Ricci, 2013). The advantages of this massage effleurage can be performed by the women of her own or by the help of others (Lowdermilk, 2013) and the way it works is 'close the gate' to inhibit the journey of excitatory pain in the central central nervous system (Mander 2004). The study mentions that women who were massaged for 20 minutes per hour during the delivery phase will be more lighter labor pain (Danuatmaja \& Meiliasari, 2004). The result of study by Wulandari (2015) got a significant result that the primiparas's pain level of labor in active phase is decreased after massage effleurage with the difference of scale is 0,79 .

This study used lavender aromatherapy and effleurage combination to assist the primiparas in controlling the pain of labor during the active phase. This combination is done as a simple but effective in the management of labor pain without having to do 
special training. It can be applied independently by the women during labor. Combining aromatherapy and effleurage can enhance relaxation during and between contractions (Lowdermilk, 2013). This study was conducted to determine the effect of combination of lavender aromatherapy with effleurage and to compare with the usual breathing relaxation.

\section{METHODS}

This study used pre-experiment design with Pretest - Post-test Control Group Design. The experimental group received lavender aromatherapy and effleurage by the primary researcher at the beginning of the active phase of labor, during the period of $4-5 \mathrm{~cm}$ of cervical dilation and during uterine contractions for 30 minutes. The control group received breathing relaxation the same routine maternity ward care. In addition, the same primary researcher accompanied respondents in the control group for 30 minutes during the period of $4-5 \mathrm{~cm}$ of cervical dilation, as done for the experimental group. Pre and post test were performed in both groups. This study aims to know the difference effect of combination of lavender aromatherapy and effleurage with breathing relaxation on pain intensity during active phase of the first stage of labor among primiparas at the Batujajar West Bandung.The independent variable were giving combination of lavender aromatherapy and effleurage.

The intensity of pain during the active phase of first stage of labor as a dependent variables was examined. Respondents were recruited from the women admitted to the community health center for normal labor. The consecutive sample of 32 laboring women divided to two groups. The study subjects were selected through a nonprobability. Inclusion criteria were: primigravida, a single fetus in cephalic position, 
with no associated risk factors, at least 37 weeks of gestation, the spontaneous onset of labor, cervical dilation of $4-5 \mathrm{~cm}$ with appropriate uterine dynamics for this phase, Sundanese ras, accompanied by close family, planned pregnancy and wish to give birth normally, no abdominal injuries, didn't receive any pharmacological pain relief substance and willing to participate in the study was included in the study. The subjects (32) were equally assigned to either one of two groups:

- Group 1: The study group, which consisted of 16 women upon whom combination of lavender aromatherapy and effleurage was received.

- Group 2: The control group, which comprised the remaining 16 women who received breathing relaxation as a routine hospital care.

The informed concern provide and gives to respondents and that must be signed by all respondents who agreed to participate in this study. Intervention is done by encouraging the women to breathe normally by closing her eyes and letting the women to relax for 30 minutes, while still inhaling lavender aromatherapy. While women inhaled lavender aromatherapy, the primary researcher did massage effleurage to women during the contraction within 30 minutes as much as 6 times massage with interval \pm . Then, the respondents to rest \pm 2 minutes, and measured post-test. Similarly, in the control group, during the contraction respondents used breathing relaxation for 30 minutes and measured post-test. The research instrument used to measure pain is the Numerical Rating Scale (NRS) with a scale of 0-10.

Statistical analysis was done after collection of data by uses computerization system. Descriptive and analytical statistics were used such as means and standard deviations. T- test dependent to know the difference of means of dependent variable before and after intervention, both in treatment group and control group. T-test 
independent were performed to determine the mean differences in labor pain after intervention in the treatment group compared with the control group.

\section{RESULTS}

According to Table 1 and 2, it was clear that mean of two groups is the same pain scale

is 7.5 (a scale of $0-10$ ) on the level of severe labor pain.

Table 1 The Average of Pain Scale of The Active Phase of Labor Before Being Given Lavender Aromatherapy and Effleurage

\begin{tabular}{cccccc}
\hline Variable & Measurement & Mean & SD & Min-Max & 95\%CI \\
\hline Labor Pain & Pretest & 7,25 & 0,775 & $6-9$ & $6,84-7,66$
\end{tabular}

Table 2 The Average of Pain Scale of The Active Phase of Labor in Control Group

\begin{tabular}{cccccc}
\hline Variable & Measurement & Mean & SD & Min-Max & 95\% CI \\
\hline Labor Pain & Pretest & 7,25 & 0,931 & $6-9$ & $6,75-7,75$ \\
\hline
\end{tabular}

According to Table 3, It shows the average of pain scale of the active-phase of labor after being given lavender aromatherapy and effleurage was 5.25. In the post-test is known that the lowest scale is 3 and the highest scale is 7 with the standard deviation of 0.931 .

Table 3 The Average of Pain Scale of The Active Phase of Labor After Being Given Lavender Aromatherapy and Effleurage

\begin{tabular}{cccccc} 
Variable & Measurement & Mean & SD & Min-Max & 95\%CI \\
\hline Labor Pain & Posttest & 5,25 & 0,931 & $3-7$ & $4,75-5,75$ \\
\hline
\end{tabular}

According to Table 4, It shows the average of pain scale of the active-phase of labor after being given breathing relaxation was 6.25 . In the post-test is known that the lowest scale is 5 and the highest scale is 8 with the standard deviation of 0.856 . 
Table 4 The Average of Pain Scale of The Active Phase of Labor After Being Given Breathing Relaxation in Control Group

\begin{tabular}{cccccc}
\hline Variable & Measurement & Mean & SD & Min-Max & 95\%CI \\
\hline Labor Pain & Pretest & 6,25 & 0,856 & $5-8$ & $5,79-6,71$ \\
\hline
\end{tabular}

According to Table 5, It shows that the result of t-test dependent (paired samples test) obtained p-value $0.000(<\alpha=0.05)$. There was a statistically significant difference regarding labor pain intensity using NRS. It can be concluded that the combination of lavender aromatherapy and effleurage can affect in reducing the pain scale of activephase of labor in primiparas.

Table 5 The Effects of Lavender Aromatherapy and Effleurage on Pain Scale of The Active Phase of Labor

\begin{tabular}{ccccccc}
\hline Variable & Measurement & N & Mean & SD & SE & p-value \\
\hline Labor Pain & Pretest & 16 & 7,25 & 0,775 & 0,194 & 0,000 \\
& Posttest & 16 & 5,25 & 0,931 & 0,233 & \\
\hline
\end{tabular}

According to Table 6, It shows that the result of t-test dependent (paired samples test) obtained $\mathrm{p}$-value $0.000(<\alpha=0.05)$. There was a statistically significant difference regarding labor pain intensity using NRS. It can be concluded that the breathing relaxation can affect in reducing the pain scale of active-phase of labor in primiparas.

Table 6 The Effects of Breathing Relaxation on Pain Scale of The Active Phase of Labor

\begin{tabular}{ccccccc}
\hline Variable & Measurement & N & Mean & SD & SE & p-value \\
\hline Labor Pain & Pretest & 16 & 7,25 & 0,931 & 0,233 & 0,000 \\
& Posttest & 16 & 5,25 & 0,856 & 0,214 & \\
\hline
\end{tabular}

According to Table 7, It shows that the result of t-test independent obtained pvalue $0.004(<\alpha=0.05)$. It can be concluded that there is a significant difference in mean pain scale of active-phase of labor after intervention with a combination of 
lavender aromatherapy and effleurage compared with breathing relaxation interventions among primiparas.

Table 7 The Difference Effect of Combination of Lavender Aromatherapy and Effleurage with Breathing Relaxation on Pain Scale of Active Phase of Labor

\begin{tabular}{ccccccc}
\hline Variable & Measurement & N & Mean & SD & SE & p-value \\
\hline Labor Pain & Pretest & 16 & 5,25 & 0,931 & 0,233 & 0,004 \\
& Posttest & 16 & 6,25 & 0,856 & 0,214 & \\
\hline
\end{tabular}

\section{DISCUSSION}

1. The average of pain scale of the active phase of labor before being given lavender aromatherapy and effleurage

The pain of labor during the active phase of first stage labor caused by uterine contractions. It's resulting dilatation and cervical effacement and uterine ischemia (Ricci, 2013). The pain will continue to increase along with increasing of cervical dilation until the full dilation $(10 \mathrm{~cm})$. The results showed an average of active phase pain 7.25 (severe pain). Primiparas women will also show an increasingly anxious, tired, compassionate and hesitant attitude to controlling pain.

Primiparas women tend to experience more anxiety, that causing tension and fear because they do not understand how to deal with labor. Excessive anxiety and fear will lead to additional secretion of catecholamines that increase pain stimulation to the brain due to decreased blood flow and increased muscle tension, where that activity will increase the perception of pain (Lowdermilk, 2013).

2. The average of pain scale of the active phase of labor after being given lavender aromatherapy and effleurage 
Based on the results of the study that the average of pain scale of the active phase of labor in the intervention group decreased to 5.25. While in the control group after breathing relaxation in the average of pain scale of the active phase of labor is 6.25. This shows the difference in the average decrease of pain scale is 1.0. The results were similar to Wahyuningsih's study (2014), where the average level of pain after lavender aromatherapy was given and effleurage decreased to 5.5 (moderate pain). Inhalation of aromatherapy lavender can help improve physical health, affect people's emotional health, improve body and refresh (Hutasoit, 2002). Giving effleurage can help women feel more fresh, relaxed and comfortable during delivery (Danuatmadja, 2004).

The study by Dewi, IP (2011) that the main content of lavender flowers is linaly acetate and linalool $(\mathrm{C1OH} 18 \mathrm{O})$. It plays an active role on the anti-anxiety effects (relaxation) which can be seen from the activity of EEG (Electro Enchepalo Gram). There is an increase in the strength of alpha and beta waves in the brain that show an increase in relaxation. The aromatherapy access through nasal cavity inhalation is a faster route than any other way, as it can directly affect the limbic system and emotional centers in the brain that will stimulate the thalamus to release the enkefalin hormone as an endogenous opioid agent that acts as a natural pain reliever (Koensoemardiyah, 2009).

Effleurage in the Lamaze method is known as "a light abdominal massage" (Lowdermilk, 2013). Effleurage is a gentle, slow, long, or uninterrupted stroke performed on the abdomen in tune with slow breathing during contraction (Danuatmadja, 2004). This massage effleurage technique aims to put light pressure on the abdominal muscles and increase physical and mental relaxation. Massage effleurage 
is given with a constant frequency and does not change. During labor, massage effleurage is performed continuously because the pain tends to increase if the massage is stopped. This happens because the nervous system is already accustomed to the stimulus (Indrayani, 2013). The results of previous research that a women who is massaged at least 20 minutes per hour during the active phase of labor will be more free from pain, because massage stimulates the body releasing endorphin compounds as natural pain reliever and can create a feeling of comfort (Danuatmadja, 2004).

3. The effects of lavender aromatherapy and effleurage on pain scale of the active phase of labor

Alternative interventions to reduce labor pain by combining aromatherapy and effleurage will enhance relaxation (Lowdermilk, 2013). Aromatherapy is safe to use by women and can be used to reduce pain and provide a calming effect of lavender (Hobbs, $\mathrm{V}, 2013)$. By inhaling aromatherapy lavender can increase alpha and beta waves in the brain and it helps create a relaxed state. Women was performed effleurage will feel more relaxed and comfortable during labor (Danuatmadja, 2004). Women respond positively to touch during labor will experience less pain (Lowdermilk, 2013).

When lavender aromatherapy is inhaled, the aromatherapy enters immediately into the limbic system in the brain that is the center of emotion, mood and memory, then the release of neurohormon endorphin and enkefalin which is a natural painkiller and neuromodulator is serotonin which serves to inhibit information nosiseptive and close defense mechanisms by inhibiting the release of substance $\mathrm{P}$ (neurotransmission of pain impulses to the central nervous system) so that the pain impulse can not be passed on to 
higher processes in the cerebral cortex (Price S, 2003., Ganong WF, 2008., Mander, 2005. , Potter PA, 2005., Coad J, 2007., Tamsuri A. 2007 in Tarkisah, 2009).

Simultaneously, the touch sensation of a massage effleurage in the abdomen will also stimulate tactile fibers in the skin so that pain signals can be inhibited. Skin stimulation with this effleurage produces messages sent through the A- $\delta$ fibers that are fibers that deliver pain quickly resulting in closed gates so that the cerebral cortex does not receive pain signals. It is in accordance with Gate Control Theory that pain fibers carry pain stimulation to the brain through small nerve fibers and travel sensations more slowly, while skin stimulation with effleurage techniques will produce impulses sent through large nerve fibers on the surface of the skin. When the sensation of touch and pain are stimulated simultaneously, the touch sensation enters to the brain more quickly and the A-delta fibers will close the gate in the brain, so the cerebral cortex can not receive the pain message as it is blocked by skin stimulation with this technique (Moonsdragon, 2008).

4. The difference effect of combination of lavender aromatherapy and effleurage with breathing relaxation on pain scale of active phase of labor

There was a significant difference of pain scale between intervention group was given combination of lavender aromatherapy and effleurage with control group was given breathing relaxation. This is due to the lack of oxygen supply to the uterine muscle is reduced because of the interval between the shortening contractions, so the supply of oxygen to the uterine muscle has not fully recovered causing the pain to increase great (Simkin, 2008). The breathing relaxation techniques in labor process will increase abdominal wall relaxation, increased oxygen supply into the uterus, enlarge the 
abdominal cavity and ultimately reduce pain caused by friction between the uterus and the abdominal wall during contraction. Breathing relaxation can also enhance physical relaxation by reducing tension and increasing emotional relaxation by reducing anxiety (Lowdermilk, 2013).

Primiparous women who have not had prior labor experience and they have not prepared themselves, the instruction to do breathing relaxation should be given early in labor process with high motivation and concentration (Lowdermilk, 2013). As the intensity of contractions increases with the progress of labor, the women becomes less aware of the surrounding environment and has difficulty in listening and understanding verbal instruction (Maryunani, 2010).

The results of this study showed an average pain scale between the intervention group and the control group both in the same category of moderate pain (4-6). But the pain scale showed differences where the mean of pain scale was lower in the intervention group given the combination of lavender aromatherapy and massage effleurage was compared with breathing relaxation.

Similar research has also been conducted by Pane (2015), that the effleurage technique can decrease the intensity of pain during labor. Where the mean pain scale before treatment of effleurage which is 5.10 and after treatment of effleurage the average value becomes 3.10. Effleurage massage has been found to be an effective therapy to decrease pain, anxiety, agitation, and a depressed mood during labor (Field et al (1997) in Brown, 2001). Field et al. reported that massaged mothers and less postpartum depression. Massage differs from the other techniques because it permits direct contact with the parturient by another person. Thus, while the procedure is applied, the parturient also receives emotional support. Massage, in addition to 
producing therapeutic effects physiologically, it's causing the parturients to tolerate less pain (Gallo, et al, 2013).

The results of this study indicate that the difference between the level of labor pain between the intervention group and the control group is not so different where the difference is only 1.0 score. This happens because the respondents in this study are less able to control factors that can affect pain such as emotional factors (anxiety and fear), so that respondents are less able to manage themselves when there is pain. Judha (2012) mentions that emotional factors (anxiety and fear) physiologically can cause uterine contractions is increasing because the condition of the body will perform defensive reactions so that the stress state stimulates the body to release stressor hormone katekolamin and adrenaline. As a result the uterus becomes more tense and pain increases.

In addition to emotional factors, the previous pain experience and labor preparation may also affect the labor pain. Tampubolon's study (2014) found that the factors that most affected labor pain during the active phase was the factor of family support, the preparation of labor and previous pain experience. Kozier (2011), the previous pain experiences changed one's sensitivity to subsequent pain. The previous pain experience factor was also expressed by Perry \& Potter (2006), that a person who has experienced recurring pain and they manage to overcome the pain then that person will be easier to interpret the pain so that the client has better coping to deal with the subsequent pain.

The factor that can affect labor pain is labor preparation. On antenatal care visits prospective parents will get the right information about childbirth, how to reduce fear, and to improve the ability to deal with pain and to increase the ability to make 
decisions. In the preparatory class of labor was also taught about relaxation techniques, distraction, muscle and respiratory control, and pregnancy exercise which aims to make the delivery process normally (Maryunani, 2010).

\section{CONCLUSION}

The average of pain scale of the active phase of labor in primiparas mother is 7.25 (severe pain). After intervention of the combination of lavender aromatherapy and effleurage the average of pain scale of labor decreased to 5.25 , while in the control group to 6.25 . Both interventions are similarly able to decrease of pain scale of the active phase of labor from severe pain scale to moderate pain scale.

Statistically there was a significant difference in average of pain scale of the active phase of labor after a combination of lavender aromatherapy and effleurage compared with breathing relaxation. The results of this study can be used as one of the reference sources in the treatment of labor pain by non-pharmacological. It is advisable to service providers in the intranatal area to provide a combination of lavender aromatherapy with effleurage as an alternative nonpharmacological therapy in addition to breathing relaxation to reduce of pain scale during active phase of labor in primiparas mother. The labor women will feel safe and comfortable, so the use of analgesic drugs can be minimized.

Further research is suggested to consider factors that may affect labor pain such as age, culture, labor experience, anxiety, labor preparation, previous pain experience, pain meanings and support system so that it can show a more significant reduction in pain. 


\section{ACKNOWLEDGMENT}

Some funding for this research was supported by the Stikes Jenderal Achmad Yani

Cimahi and Batujajar Community Health Center.

\section{REFERENCES}

Afifah, D. (2011). Perbedaan tingkat Nyeri Persalinan Kala I Pada Ibu Bersalin Normal Primiparas dan Multigravida di RB Nur Hikmah Desa Kuwaron Gubug Kabupaten Grobogan Tahun 2011. Jurnal Kebidanan UNIMUS, 1(1). http://jurnal.unimus.ac.id/.

Brown, Douglas, \& Plaster. (2001). Women's Evaluation of Intrapartum Nonpharmacological Pain Relief Methods Used during Labor. The Journal of Perinatal Education, 10 (3).

Danuatmadja, Benny., \& Meiliasari, Mila. (2004). Persalinan Normal Tanpa Rasa Sakit. Jakarta : Puspa Swara.

Dewi, IP. (2011). Aromaterapi Lavender sebagai Media Relaksasi. Artikel. Bali : Bagian Farmasi Universitas Kedokteran Udayana.

Gallo et al. (2013). Massage reduced severity of pain during labour: a randomised trial. Journal of Physiotherapy, Vol. 59

Hobbs, V. (2013). Aromatherapy In Pregnancy. Phoenixtherapies.com.au/wpcontent/uploads/2014/09/aromatherapy-used-in-pregnancy.pdf. II 2 - 19.

Hutasoit, A.S (2002). Panduan Praktis Aromatherapy. Jakarta : PT Gramedia Pustaka Utama

Indrayani. (2013). Asuhan Persalinan dan Bayi Baru Lahir. Jakarta : TIM

Judha, dkk. (2012). Teori Pengukuran Nyeri dan Nyeri Persalinan. Yogyakarta : Nuha Medika.

Koensoemardiyah. (2009). A-Z Aromaterapi Untuk Kesehatan, Kebugaran dan Kecantikan. Yogyakarta : Lily Publisher.

Kozier, \& Erb. (2011). Buku Ajar Fundamental Keperawatan Edisi 7 Volume 2. Jakarta : EGC.

Lowdermilk et al. (2013). Keperawatan Maternitas. Edisi 8 Buku I. Singapore : Elsevier. 
Mander, Rosemary. (2004). Nyeri Persalinan. Jakarta : EGC.

Maryunani, Anik. (2010). Nyeri Dalam Persalinan : Teknik dan Cara Penangannya. Jakarta : TIM.

Monsdragon. (2004). Pregnancy Information (Effleurage dan massage). http://www.monsdragon.org/pregnancy/effleurage.html [Diperoleh tanggal 20 Februari 2016].

Pane, N A. (2015). Efektifitas Teknik Effleurage Terhadap Penurunan Intensitas Nyeri Persalinan Kala I. http://repository.usu.ac.id/handle/123456789/45334.

Perry \& Potter. (2006). Buku Ajar Fundamental Keperawatan : Konsep, Proses dan Praktik edisi 4 vol. 2. Jakarta : EGC.

Price, Shirley. (2011). Everyday Aromatherapy (Using Essential Oils Safely and successfully).

www.shirleypriceessentia.com/files/shirleypriceeverydayguid.2011.pdf. II 5 - 17.

Ricci, SS. (2013). Essentials of Maternity, Newborn, and Women's Health Nursing. Edisi 3. China : LWW

Simkin, P. (2008). Panduan Lengkap Kehamilan, Melahirkan \& Bayi. Jakarta : Arcan. Tampubolon, E.A. (2014). Faktor-Faktor Yang Mempengaruhi Nyeri Persalinan Pada Kala I Di Klinik Bersalin Delima Medan Belawan. http://repository.usu.ac.id/handle/123456789/44242.

Tarkisah. (2009). Penurunan Nyeri Persalinan Primiparas Kala I Fase Aktif Pasca Penghirupan Aromaterapi Lavender di RB Kasih Ibu Jatirogo Kab. Tuban Jawa Timur. Journal FK Unpad, 44(1). http://journal.fk.unpad.ac.id/.

Wahyuningsih, M. (2014). Efektifitas Aromaterapi Lavender dan Massage Effleurage terhadap Tingkat Nyeri Persalinan Kala I di BPS Utami dan PONEK RSUD Karanganyar. Skripsi. Surakarta. Stikes Kusuma Husada.

Wulandari, P. (2015). Pengaruh Massage Effleurage Terhadap Pengurangan Tingkat Nyeri Persalinan Kala I Fase Aktif pada Primiparas di Ruang Bougenville RSUD Tugurejo Semarang. Jurnal Keperawatan Maternitas Persatuan Perawat Nasional Indonesia, 3(1). http://ppnijateng.org/. 